\title{
PENGARUH PEMBERIAN EKSTRAK DAUN BELIMBING WULUH (Averrhoa bilimbi L.) TERHADAP PENYEMBUHAN LUKA SAYAT PADA MENCIT JANTAN (Mus musculus L.)
}

\section{(THE EFFECT OF WULUH STARFRUIT LEAF (Averrhoa bilimbi L.) EXTRACT ON INCISION WOUND IN MALE MICE (Mus musculus L.))}

\author{
I GUSTI AGUNG AYU KUSUMA WARDANI ${ }^{\bullet}{ }^{1}$, KETUT AGUS ADRIANTA ${ }^{1}$, FITRIA MEGAWATI $^{1}$ \\ ${ }^{1}$ Akademi Farmasi Saraswati Denpasar, Jalan Kamboja No.11A, Denpasar, Bali
}

\begin{abstract}
Abstrak: Kulit merupakan perlindungan pertama pada tubuh. Kulit mempunyai fungsi yang begitu penting untuk melindungi tubuh dari gangguan cuaca, mikroorganisme seperti bakteri, jamur, virus dan zat-zat kimia sehingga sering kali kulit mudah terkena luka. Penyembuhan luka merupakan suatu proses yang kompleks dan dinamis karena melibatkan suatu kegiatan bioseluler dan biokimia yang terjadi saling berkesinambungan yang terbagi dalam tiga fase yaitu fase inflamasi, fase poliferasi dan fase maturasi. Penelitian ini merupakan penelitian eksperimental dengan rancangan randomized control group pretest posttest design. Pengujian menggunakan 18 ekor mencit yang dibagi menjadi 3 kelompok yaitu kontrol negatif, ekstrak belimbing wuluh $200 \mathrm{mg} / \mathrm{Kg} \mathrm{BB}$ dan ekstrak belimbing wuluh $400 \mathrm{mg} / \mathrm{Kg}$ BB. Semua mencit disayat pada daerah punggung menggunakan scalpel sepanjang $2 \mathrm{~cm}$. Pengamatan luka dilakukan setiap hari selama 10 hari, panjang luka sayat diukur menggunakan jangka sorong. Analisis data diuji secara statistik dengan menggunakan metode SPSS ver.16. Hasil uji Wilcoxon pada masing-masing kelompok diperoleh nilai sig. $0,000(\mathrm{p}<0,005)$, hal ini menunjukkan ada perbedaan yang bermakna pada penyembuhan luka sayat sebelum dan setelah perlakuan. Hasil uji Mann Whitney menunjukkan antara kelompok kontrol negatif dengan kelompok ekstrak $200 \mathrm{mg} / \mathrm{Kg}$ $\mathrm{BB}$ dan $400 \mathrm{mg} / \mathrm{Kg} \mathrm{BB}$, diperoleh nilai sig. sebesar 0,038 dan 0,002 (secara berurutan) ( $<<0,005)$. Hal ini menunjukkan ada perbedaan efektivitas ekstrak belimbing wuluh dengan kontrol negatif (aquadest). Pada kelompok ekstrak $200 \mathrm{mg} / \mathrm{Kg}$ BB dengan kelompok ekstrak $400 \mathrm{mg} / \mathrm{Kg}$ BB diperoleh nilai sig. 0,317 (p>0,05). Hal ini menunjukkan bahwa efektivitas ekstrak belimbing wuluh $200 \mathrm{mg} / \mathrm{Kg}$ BB dengan $400 \mathrm{mg} / \mathrm{Kg}$ BB tidak ada perbedaan secara bermakna dalam menyembuhkan luka sayat. Berdasarkan hasil penelitian dapat disimpulkan bahwa ekstrak daun belimbing wuluh dengan $200 \mathrm{mg} / \mathrm{Kg}$ BB dapat menyembuhkan luka sayat pada mencit.
\end{abstract}

Kata kunci: Belimbing wuluh, luka sayat

\begin{abstract}
Skin is the first protection of the body. The skin has such an important function to protect the body from weather disturbances, microorganisms such as bacteria, fungi, viruses and chemicals so that the skin is often susceptible to injury. Wound healing is a complex and dynamic process because it is an ongoing bio cellular and biochemical activity that is divided into three phases: the inflammatory phase, the proliferation phase and the maturation phase. This research is an experimental research with randomized control group pretest-posttest design. Tests using 18 mice were divided into 3 groups of negative control, Wuluh starfruit leaf extract $200 \mathrm{mg} / \mathrm{Kg} \mathrm{BB}$ and Wuluh starfruit leaf extract $400 \mathrm{mg} / \mathrm{Kg}$ BB. All mice were slashed on the back using a $2 \mathrm{~cm}$ long scalpel. Wound observation was performed every day for 10 days, measured the length of the cut wound in the afternoon using a sliding term. Data analysis was statistically tested using SPSS ver.16 method. Wilcoxon test results in each group obtained sig value. $0.000(\mathrm{p}<0.005)$, this indicates that there is a significant difference in the healing of the cuts before and after the treatment. Mann Whitney test results showed that between the negative control group and the extract group of $200 \mathrm{mg} / \mathrm{Kg} \mathrm{BW}$ and $400 \mathrm{mg} / \mathrm{Kg} \mathrm{BW}$, the sig value was obtained of 0.038 and 0.002 (respectively) ( $\mathrm{p}<0.005)$. This shows that there is a difference of effectiveness of Wuluh starfruit leaf extract with negative control (aquadest). In the extract group of 200 $\mathrm{mg} / \mathrm{Kg} \mathrm{BW}$ with the extract group of $400 \mathrm{mg} / \mathrm{Kg} \mathrm{BW}$ obtained the sig value. 0.317 (p>0.05). This shows that the effectiveness of Wuluh starfruit leaf extract $200 \mathrm{mg} / \mathrm{Kg} \mathrm{BB}$ with $400 \mathrm{mg} / \mathrm{Kg}$ BB there is no significant difference in healing cuts. Based on the results of the study can be concluded that the Wuluh starfruit leaf extract $200 \mathrm{mg} / \mathrm{Kg}$ BB can heal cuts in the mice.
\end{abstract}

Keywords: Wuluh starfruit leaf, wound cut

• email korespondensi: kusumawardani210488@gmail.com 


\section{PENDAHULUAN}

Obat tradisional telah lama dikenal dan digunakan oleh semua lapisan masyarakat di Indonesia untuk tujuan pengobatan maupun perawatan kesehatan. Pemanfaatan tanaman berkhasiat obat di masyarakat terus berkembang dan diwariskan ke generasi selanjutnya. Perkembangan obat tradisional ini dimulai dari beberapa ramuan tradisional yang berkembang di tengah masyarakat, yang kemudian berkembang menjadi suatu ramuan yang diyakini memiliki khasiat tertentu bagi tubuh manusia (Wasito, 2011).

Kulit merupakan perlindungan pertama pada tubuh. Fungsi kulit yaitu melindungi tubuh dari gangguan cuaca, mikroorganisme seperti bakteri, jamur, virus dan zat-zat kimia. Kulit mempunyai fungsi yang begitu penting sehingga sering kali kulit mudah terkena luka. Luka merupakan pemisahan jaringan kulit, selaput lendir, atau permukaan suatu organ secara traumatik (Harvey, 2005). Bentuk luka berbedabeda tergantung penyebabnya, ada luka yang terbuka dan tertutup. Salah satu contoh luka terbuka adalah insisi/luka sayat dimana terdapat robekan linier pada kulit dan jaringan yang berada di bawahnya (Pusponegoro, 2005).

Luka sayat merupakan luka yang terjadi karena teriris oleh suatu instrumen yang tajam. Adapun ciri-ciri luka sayat diantaranya luka terbuka, nyeri, panjang luka lebih besar daripada dalamnya luka (Berman, 2009).

Pentingnya penanganan luka secara optimal telah mendorong pesatnya perkembangan ilmu tentang luka, penyembuhan, dan penanganan luka. Saat ini penggunaan bahan herbal untuk penggantian obat-obat kimia telah banyak dilakukan (Harvey, 2005). Salah satu tanaman yang dipercaya oleh masyarakat dapat menyembuhkan luka yaitu tanaman belimbing wuluh (Averrhoa bilimbi L.). Senyawa yang terdapat pada ekstrak daun belimbing wuluh antara lain flavonoid, saponin, triterpenoid dan tanin (Hayati, dkk., 2010). Penelitian yang dilakukan oleh Diah (2014) menyatakan bahwa daun belimbing wuluh mempunyai aktivitas antibakteri.

Berdasarkan latar belakang diatas, maka dilakukan penelitian untuk mengetahui pengaruh pemberian ekstrak daun belimbing wuluh (Averrhoa bilimbi L.) terhadap penyembuhan luka sayat pada mencit jantan (Mus musculus L.).

\section{METODE PENELITIAN}

Rancangan Penelitian. Jenis penelitian yang digunakan adalah penelitian eksperimental dengan menggunakan metode randomized control group pretest-posttest design.

Bahan. Bahan yang digunakan adalah simplisia daun belimbing wuluh yang diperoleh di Desa Selabih, Kecamatan Selemadeg Barat, Kabupaten Tabanan, Bali, etanol $80 \%$, kertas saring, aquades, ketamine, xylazine.

Alat. rotary evaporator, oven, blender, corong Buchner (vakum), kertas saring, timbangan, alat gelas, sonde, ayakan, jangka sorong, spuit injeksi, pisau, gunting, dan scalpel.

Pembuatan ekstrak daun belimbing wuluh. Serbuk simplisia daun belimbing wuluh ditimbang 300 gram dan dimaserasi menggunakan 1,500 mL pelarut etanol $80 \%$ dalam bejana tertutup rapat, terlindung dari cahaya. Maserat diaduk konstan selama 60 menit menggunakan batang pengaduk. Hari kedua, maserat diaduk lagi selama 60 menit, ditutup dan disimpan kembali. Hari ketiga, maserat disaring dengan corong Buchner (vakum) sehingga diperoleh filtrat-1. Ampas dimaserasi kembali dengan jenis dan jumlah pelarut yang sama dengan prosedur seperti di atas. Hari keenam, maserat disaring kembali untuk memperoleh filtrat-2 lalu digabung dengan filtrat-1. Filtrat diuapkan dengan rotary evaporator pada suhu $40^{\circ} \mathrm{C}$, sehingga diperoleh ekstrak kental.

Pembuatan Ekstrak Belimbing Wuluh. Serbuk simplisia daun belimbing wuluh ditimbang sebanyak 300 gram dan dimaserasi menggunakan pelarut etanol $80 \%(1,5 \mathrm{~L})$ dalam bejana tertutup rapat dan terlindung dari cahaya. Maserat diaduk konstan selama 60 menit menggunakan batang pengaduk. Hari kedua, maserat diaduk lagi selama 60 menit, ditutup dan disimpan kembali. Hari ketiga, maserat disaring dengan corong Buchner (vakum) sehingga diperoleh filtrat-1. Ampas dimaserasi kembali dengan jenis dan jumlah pelarut yang sama dengan prosedur seperti diatas. Hari keenam, maserat disaring kembali untuk memperoleh filtrat-2 lalu digabung dengan filtrat1. Filtrat diuapkan pada suhu $40^{\circ} \mathrm{C}$, sehingga diperoleh ekstrak kental.

Penyiapan Hewan Coba. Hewan coba yang akan digunakan dalam penelitian ini adalah mencit sebanyak 18 ekor. Dibagi dalam 3 kelompok yaitu 
kelompok 1 diberi aquadest (kontrol negatif), kelompok 2 dan kelompok 3 sebagai kelompok uji diberi ekstrak daun belimbing wuluh dengan dosis masing-masing $200 \mathrm{mg} / \mathrm{Kg}$ BB dan $400 \mathrm{mg} / \mathrm{Kg}$ BB. Semua perlakuan diberikan sebanyak 2,5 $\mathrm{ml} / 100 \mathrm{~g} \mathrm{BB}$ secara acak. Setiap kelompok terdiri dari 6 ekor mencit jantan yang sehat dengan umur berkisar 8-12 minggu dan berat 30-40 gram.

Dosis Ekstrak Daun Belimbing Wuluh. Dosis ekstrak daun belimbing wuluh yang digunakan dalam penelitian ini adalah $200 \mathrm{mg} / \mathrm{Kg} \mathrm{BB}$ dan $400 \mathrm{mg} / \mathrm{Kg}$ BB

Perlakuan Hewan Coba. Sebelum pembuatan luka, mencit terlebih dahulu dianestesi menggunakan ketamine dan xylazine dengan perbandingan 1:1. Rambut disekitar punggung mencit dicukur dan dibersihkan dengan alkohol $70 \%$, kemudian dilakukan sayatan pada daerah punggung menggunakan scalpel sepanjang $2 \mathrm{~cm}$. Dari hari-1 sampai ke hari-10 semua kelompok diberikan perlakuan menurut kelompoknya. Dilakukan pengukuran panjang penyembuhan luka sayat menggunakan jangka sorong setiap 2 hari sekali sampai hari ke-10.

Analisis Data. Data yang diperoleh dianalisis dengan menggunakan program statistika metode SPSS ver.16. Untuk mengetahui sebaran data normal atau tidak, dilakukan uji normalitas dengan menggunakan uji Shapiro-Wilk. Selanjutnya dilakukan uji Wilcoxon dan Mann Whitney.

\section{HASIL DAN PEMBAHASAN}

Hasil skrining fitokimia yang telah dilakukan menunjukkan bahwa ekstrak daun belimbing wuluh mengandung metabolit sekunder flavonoid, saponin, dan tanin.

Dari penelitian luka sayat yang dilakukan menunjukkan adanya penyembuhan luka sayat pada masing-masing kelompok, yang dapat dilihat pada Gambar 1.

Gambar 1 menunjukkan bahwa pada kelompok kontrol negatif panjang rata-rata luka sayat pada hari ke-10 relatif lebih tinggi dibandingkan kelompok ekstrak $200 \mathrm{mg} / \mathrm{Kg}$ BB dan $400 \mathrm{mg} / \mathrm{Kg}$ BB. Hal ini disebabkan pada ekstrak daun belimbing wuluh mengandung metabolit sekunder yang efektif dalam menyembuhkan luka sayat.

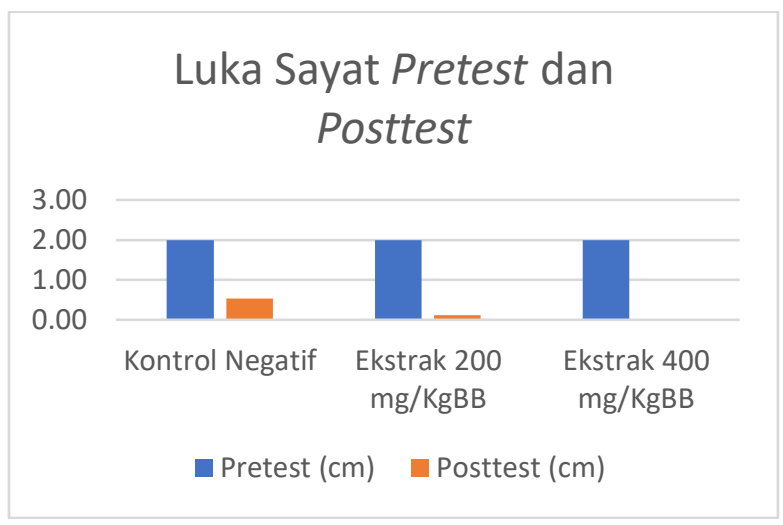

Gambar 1. Hasil rata-rata panjang luka sayat (Pretest dan Posttest)

Senyawa flavonoid yang terkandung dalam daun belimbing wuluh berperan sebagai agen antiinflamasi, antioksidan, mencegah terjadinya penyumbatan pada pembuluh darah, melancarkan peredaran darah ke seluruh tubuh, serta membantu mengurangi rasa sakit jika terjadi pembengkakan atau perdarahan (Wahyuningsih, S., dkk, 2006). Flavonoid juga berperan sebagai antimikroba yang dapat mempercepat proses penyembuhan luka (Ambiga, et al, 2007).

Kandungan tanin berfungsi sebagai adstringen yang dapat mengecilkan pori-pori kulit, menghentikan eksudat dan pendarahan ringan (Anief, 1997). Senyawa tanin mengandung senyawa antibakteri dimana senyawa tersebut membantu mengkerutkan dinding sel atau membran sel sehingga menghambat permeabilitas bakteri untuk berkembang (Ajizah, 2004).

Saponin memiliki kemampuan sebagai antiseptik yang berfungsi sebagai pembunuh kuman atau mencegah pertumbuhan mikroorganisme yang bisa timbul pada luka sehingga luka tidak mengalami infeksi yang berat (Robinson, 1995). Senyawa saponin juga membantu merangsang pembentukan sel epitel yang baru dan mendukung proses re-epitelisasi, karena semakin cepat proses re-epitelisasi maka semakin cepat proses penyembuhan luka (Prasetyo., et al. 2010).

Pada kelompok kontrol negatif tetap terjadi penyembuhan luka, walaupun luka tidak menutup sempurna seperti pada kelompok ekstrak. Hal ini disebabkan karena tubuh yang sehat mempunyai kemampuan alami untuk melindungi dan memulihkan dirinya (Klokke, 1980).

\section{Analisis Statistik}

Panjang luka sayat diuji normalitasnya dengan menggunakan uji Shapiro-Wilk. Hasil 
analisis menunjukkan bahwa data tidak terdistribusi normal $(\mathrm{p}<0,05)$.

Hasil uji Wilcoxon pada masing-masing kelompok diperoleh nilai sig. 0,000 ( $\mathrm{p}<0,005)$, hal ini menunjukkan ada perbedaan yang bermakna pada penyembuhan luka sayat sebelum dan setelah perlakuan.

Analisis kemaknaan antar kelompok diuji dengan uji Mann Whitney. Pada kelompok kontrol negatif dengan kelompok ekstrak $200 \mathrm{mg} / \mathrm{Kg}$ BB dan $400 \mathrm{mg} / \mathrm{Kg} \mathrm{BB}$, diperoleh nilai sig. sebesar 0,038 dan 0,002 (secara berurutan) $(\mathrm{p}<0,005)$. Hal ini menunjukkan ada perbedaan efektivitas ekstrak belimbing wuluh dengan kontrol negatif (aquadest). Pada kelompok ekstrak $200 \mathrm{mg} / \mathrm{Kg} \mathrm{BB}$ dengan kelompok ekstrak $400 \mathrm{mg} / \mathrm{Kg} \quad \mathrm{BB}$ diperoleh nilai sig. $0,317 \quad(\mathrm{p}>0,05)$. Hal ini menunjukkan bahwa efektivitas ekstrak belimbing wuluh $200 \mathrm{mg} / \mathrm{Kg}$ BB dengan $400 \mathrm{mg} / \mathrm{Kg}$ BB tidak ada perbedaan secara bermakna dalam menyembuhkan luka sayat. Hasil uji Mann Whitney dapat dilihat pada Tabel 1.

Tabel 1. Hasil Uji Mann Whitney

\begin{tabular}{|c|c|c|c|}
\hline \multicolumn{2}{|c|}{ Kelompok perbandingan } & $\mathrm{P}$ & Keterangan \\
\hline \multirow{2}{*}{$\begin{array}{l}\text { Kontrol } \\
\text { negatif }\end{array}$} & $\begin{array}{l}\text { Ekstrak } 200 \\
\mathrm{mg} / \mathrm{Kg} \mathrm{BB}\end{array}$ & 0,038 & $\begin{array}{l}\text { Ada perbedaan } \\
\text { bermakna }\end{array}$ \\
\hline & $\begin{array}{l}\text { Ekstrak } 400 \\
\mathrm{mg} / \mathrm{Kg} \mathrm{BB}\end{array}$ & 0,002 & $\begin{array}{l}\text { Ada perbedaan } \\
\text { bermakna }\end{array}$ \\
\hline \multirow{2}{*}{$\begin{array}{l}\text { Ekstrak } \\
200 \\
\mathrm{mg} / \mathrm{Kg} \\
\mathrm{BB}\end{array}$} & $\begin{array}{l}\text { Kontrol } \\
\text { negatif }\end{array}$ & 0,038 & $\begin{array}{l}\text { Ada perbedaan } \\
\text { bermakna }\end{array}$ \\
\hline & $\begin{array}{l}\text { Ekstrak } 400 \\
\mathrm{mg} / \mathrm{Kg} \mathrm{BB}\end{array}$ & 0,317 & $\begin{array}{l}\text { Tidak ada } \\
\text { perbedaan } \\
\text { bermakna }\end{array}$ \\
\hline \multirow{2}{*}{$\begin{array}{l}\text { Ekstrak } \\
400 \\
\mathrm{mg} / \mathrm{Kg} \\
\mathrm{BB}\end{array}$} & $\begin{array}{l}\text { Kontrol } \\
\text { negatif }\end{array}$ & 0,002 & $\begin{array}{l}\text { Ada perbedaan } \\
\text { bermakna }\end{array}$ \\
\hline & $\begin{array}{l}\text { Ekstrak } 200 \\
\mathrm{mg} / \mathrm{Kg} \mathrm{BB}\end{array}$ & 0,317 & $\begin{array}{l}\text { Tidak ada } \\
\text { perbedaan } \\
\text { bermakna }\end{array}$ \\
\hline
\end{tabular}

\section{KESIMPULAN}

Berdasarkan penelitian yang telah dilakukan dapat disimpulkan bahwa ekstrak daun belimbing wuluh dosis $200 \mathrm{mg} / \mathrm{Kg} \mathrm{BB}$ dapat menyembuhkan luka sayat.

\section{DAFTAR PUSTAKA}

Ajizah A. 2004. Sensitivitas Salmonella Typhimurium Terhadap Ekstrak Daun
Psidium Guajava L. Bioscientiae Vol.1 No.1. pp: 8-31

Anief, M. 1997. Formulasi Obat Topikal Dengan Dasar Penyakit kulit. Gajah Mada University Press : Yogyakarta

Berman, Audrey. 2009. Buku Ajar Praktik Keperawatan Klinis Edisi Kelima. EGC : Jakarta.

Diah, S, L., 2014, Effect Of Wuluh Starfruit Leaf Extract For Streptococcus mutans Growth, Jurnal Faculty of Medicine University Lampung, Lampung.

Harvey C. 2005. Wond healing. Orthop Nursing, 24(2): 143-159.

Hayati, E. K., Jannah A, dan Mukhlisoh W., 2010, Pengaruh Ekstrak Tunggal dan Gabungan Daun Belimbing Wuluh (Averrhoa Bilimbi Linn) Terhadap Efektivitas Antibakteri Secara In Vitro, Kimia, UIN Malang, Malang.

Klokke. 1980. Pedoman Untuk Pengobatan Luar Penyakit Kulit. PT. Gramedia: Jakarta.

Prasetyo BF, Wientarsih I, Priosoeryanto BP. 2010. Aktivitas Sediaan Gel Ekstrak Batang Pohon Pisang Ambon Dalam Proses Penyembuhan Luka Pada Mencit. Jurnal Veteriner 1 (2): 70-73.

Pusponegoro, A. D. 2005. Luka Dalam Buku Ajar Ilmu Bedah Edisi ke-2. EGC : Jakarta.

Robinson. T. 1995, Kandungan Organik Tumbuhan Tingkat Tinggi. ITB : Bandung.

Wasito, H. 2011, Obat Tradisional Kekayaan Indonesia, Graha Ilmu, Yogyakarta.

Wahyuningsih, S. Soemardji, A.A. \& Febiyanti, D. 2006. Efek Gel Lidah Buaya (Aloe barbadensis Mill) Terhadap Penyembuhan Luka Bakar Eksperimen Pada Tikus Wistar Betina. Prosiding seminar nasional tumbuhan obat Indonesia XXIX. 73-81. 